\title{
Homograft replacement of aortic root with reimplantation of coronary arteries Results after one to five years
}

\author{
JANE SOMERVILLE, DONALD ROSS \\ From Paediatric and Adolescent Unit, National Heart Hospital, London
}

SUMMARY Between 1976 and 1980, 26 patients aged 7 to 36 years had complete replacement of the aortic root with a valved homograft into which the coronary arteries were reimplanted. The main indication was the tunnel type of obstruction combining a hypoplastic valve ring, often with supra and subvalvar stenosis. Nineteen had previous operations for congenital left ventricular outflow obstructions.

There was one perioperative death and one late death from progressive pulmonary vascular disease. Relief of left ventricular outflow tract obstruction was achieved in a majority of cases and the valves were entirely competent. With increasing experience, the initial problems of malalignment and torsion of the coronary arteries and complete heart block have been largely overcome.

This operation provides an alternative technique for the management of diffuse left ventricular outflow tract obstruction and related problems in young patients. The long-term results of aortic homografts are well documented, and by eliminating the problems of aortic regurgitation it is anticipated that this may represent an advance in treatment.

The relief of "tunnel"1 left ventricular outflow tract obstruction occurring as a primary lesion or after previous aortic valvotomy and resection of fixed subaortic stenosis is difficult and is associated with significant morbidity and mortality. ${ }^{2}$ The problems are to fit an adequate aortic valve replacement into a small, hypoplastic aortic root, and to relieve the associated diffuse muscular subvalvar and sometimes supravalvar narrowing.

With the increasing numbers of reoperations on patients who have had previous surgery for various forms of aortic stenosis ${ }^{34}$ a solution is urgently needed for this problem.

After adequate excision of the distorted, narrow aortic root and aortic valve, the left ventricular outflow tract opens up, and it becomes possible to put in an adult homograft aortic root and valve and reimplant the coronary arteries into the homograft. ${ }^{5}$ This provides good relief of obstruction and was first performed in 1972 (DR) for the emergency replacement of an infected Starr valve; the patient has maintained a good clinical and haemodynamic result to date.
It is now our practice to use this operation in young patients with complex left ventricular outflow obstruction. Since 1976, in the National Heart Hospital, the operation has been used in tunnel obstructions and other forms of aortic root and valve disease where simpler forms of aortic valve replacement or enlargement of the ring have not produced good results, and we report our experience of this technique from 1976 to 1980 .

\section{Technique}

In managing the complex hypoplastic aortic root, the aim is to excise the whole tunnel area of thickened hypoplastic tissue, which often includes a supravalvar stenosis, the thickened valve, a hypoplastic ring, and additional subvalvar endocardial proliferation (Fig. 1a).

The upper limit of the incision is at least $1 \mathrm{~cm}$ above the point of commissural attachment of the valve, and the lower extent of the incision is across the outflow tract of the left ventricle at the point of insertion of the right coronary sinus into the septum anteriorly and across the subvalvar curtain of the mitral valve posteriorly. In the angle between the right and non-coronary cusps the incision skirts the 

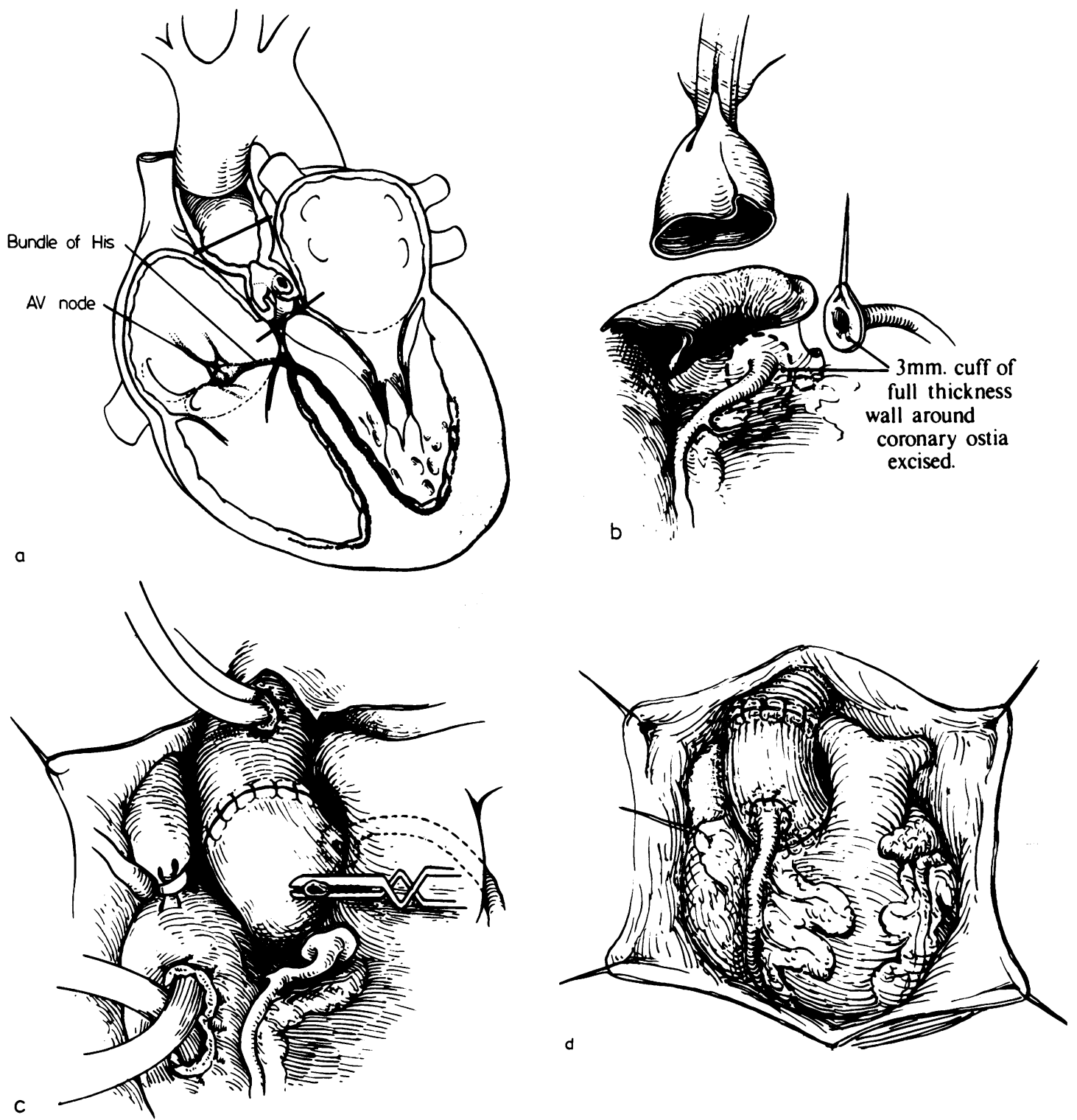

Fig. 1 Drawings of stages of aortic root replacement with an aortic homograft and with reimplantation of the coronary arteries. (a) Extent of excision of the aortic root and position of the conducting tissue. (b) The left coronary has been excised with a cuff of tissue and will be sutured into the new aortic root in the original position of the left coronary artery. (c) After completion of the upper suture line the aortic root is distended to determine the most appropriate site for attachment of the right coronary artery. (d) The completed aortic root and valve replacement as seen from the front.

upper margin of the membranous septum in order to avoid the conducting tissue. The coronary orifices are preserved with a 2 to $3 \mathrm{~mm}$ cuff of surrounding aortic wall. Such an incision results in a remarkable enlargement of the left ventricular outflow and makes it possible to insert an adult sizød aortic root of at least
$2 \mathrm{~cm}$ in diameter.

Conventional hypothermic bypass is established and cardioplegic arrest of the heart is achieved with Ringer's solution and potassium $(20 \mathrm{mg} / \mathrm{l})$.

As a first step, the aorta is opened transversely (Fig. 1b) and once a decision to replace the root has 
been made it is completely transected and the upper end is freed from the pulmonary artery.

The coronary arteries are identified, and it is advisable to pass curved blunt probes into them to identify their direction at this stage and during their subsequent mobilisation. The aortic wall is incised in such a way as to allow a full thickness cuff of aortic wall about $3 \mathrm{~mm}$ around both coronary arteries (Fig. 1b), after which the remaining aortic wall is excised boldly across the anterior mitral valve cusp and more circumspectly anteriorly across the membranous septum so as to clear the conducting tissue. The excision from the septum anteriorly leaves some fibrous remnants for the later attachment of sutures to the muscle. Any excess subvalvar endocardial proliferations and extensions can now be enucleated by blunt dissection and if the subvalvar hypertrophy is gross a formal subvalvar myotomy and wedge resection of muscle can be added.

With a bougie in place in the left coronary artery this vessel should be mobilised freely and carefully so as to avoid subsequent tension or torsion when it is reattached to a larger aortic homograft.

Multiple interrupted 4/0 Prolene sutures are now used to attach the lower margin of the horizontally trimmed homograft to the corresponding areas of the previous valve excision. At least 24 sutures are required, dividing the circumference into four sections with six to eight sutures in each. It is convenient to tie these down over a thin $4 \mathrm{~mm}$ strip of Teflon felt to aid haemostasis and to avoid cutting through the muscle of the homograft.

The left coronary artery is now attached to a corresponding excised orifice in the left coronary sinus of

Table 1 Dominant lesion for which previous surgery and/or root replacement was performed

\begin{tabular}{|c|c|c|c|c|c|c|c|c|}
\hline \multirow{2}{*}{$\begin{array}{l}\text { Case } \\
\text { No. }\end{array}$} & \multirow[t]{2}{*}{ Previous operation } & \multirow{2}{*}{$\begin{array}{l}\text { Age } \\
(y)\end{array}$} & \multicolumn{6}{|c|}{ Aortic valve and root replacement } \\
\hline & & & $\begin{array}{l}\text { Dominant } \\
\text { lesion }\end{array}$ & $\begin{array}{l}\text { Tunnel } \\
\text { obstr. }\end{array}$ & $\begin{array}{l}\text { Age } \\
(y)\end{array}$ & Myotomy & $\begin{array}{l}\text { Wedge } \\
\text { resection }\end{array}$ & Other surgery at same time \\
\hline 1 & & & AVS & + & 11 & - & - & - \\
\hline 2 & & & AVS & + & 7 & + & + & $\begin{array}{l}\text { Ligation of PDA, } \\
\text { repair of LCA }\end{array}$ \\
\hline $\begin{array}{l}3 \\
4\end{array}$ & Aortic valyotomy & & AVS & + & 12 & + & + & - \\
\hline & $\begin{array}{l}\text { Aortic valvotomy } \\
\text { + relief supraAS }\end{array}$ & 11 & SupraAS & + & 17 & + & + & Repair of RCA \\
\hline 5 & Aortic valvotomy & 11 & $\mathrm{AR}$ & - & 16 & - & - & - \\
\hline $\begin{array}{l}6 \\
7\end{array}$ & AVR-Starr for AS+AR & 26 & $\begin{array}{l}\text { AR } \\
\text { AR }\end{array}$ & 二 & $\begin{array}{l}15 \\
36\end{array}$ & 二 & 二 & - \\
\hline 8 & $\begin{array}{l}\text { Aortic valvotomy } \\
\text { AVR-Hancock for AS }\end{array}$ & $\begin{array}{r}6 \\
15\end{array}$ & AVS & + & 16 & $\overline{+}$ & $\overline{+}$ & $\begin{array}{l}\text { CVG's to LAD and marginal } \\
\text { branch of circumflex }\end{array}$ \\
\hline $\begin{array}{r}9 \\
10\end{array}$ & Resection of fixed subAS & 9 & SubAS & + & 20 & + & + & - \\
\hline $\begin{array}{l}10 \\
11\end{array}$ & Aortic valvotomy & 8 & $\begin{array}{l}\text { AVS } \\
\text { AVS }\end{array}$ & $\overline{+}$ & 22 & - & - & - \\
\hline 12 & $\begin{array}{l}\text { Aortic valvotomy } \\
\text { Aortic valvotomy }\end{array}$ & $\begin{array}{l}3 \\
8\end{array}$ & AVS & + & 13 & $\overline{+}$ & $\overline{+}$ & $\overline{-}$ \\
\hline 13 & & & AR (congen.) & - & 14 & - & - & Mitral annuloplasty \\
\hline 14 & $\begin{array}{l}\text { Resection coarct.; } \\
\text { AVR-homograft for AS }\end{array}$ & $\begin{array}{l}11 \\
14\end{array}$ & & - & 25 & - & - & $\begin{array}{l}\text { CVG to RCA; insertion of } \\
\text { pacemaker for CHB }\end{array}$ \\
\hline 15 & Aortic valvotomy & 6 & AVS & + & 13 & + & + & - \\
\hline 16 & Resection of fixed subAS & 10 & SubAS & + & 14 & + & + & - \\
\hline 17 & Resection of fixed subAS & & SubAS & - & 15 & + & - & - \\
\hline 18 & $\begin{array}{l}\text { Resection coarct.; } \\
\text { aortic valvotomy }\end{array}$ & $1 / 12$ & AVS & + & 8 & + & + & - \\
\hline 19 & $\begin{array}{l}\text { Closure of VSD+AVR- } \\
\text { homograft for AR }\end{array}$ & 5 & $\mathbf{A R}$ & - & 8 & - & - & - \\
\hline 20 & Aortic valvotomy & 15 & $\mathrm{AR}$ & - & 21 & - & - & - \\
\hline 21 & Resection of fixed subAS & 15 & SubA\$ & + & 27 & + & - & - \\
\hline 22 & $\begin{array}{l}\text { AVR-homograft for AR (SBE); } \\
\text { AVR-Starr for AR (SBE) }\end{array}$ & $\begin{array}{l}19 \\
23\end{array}$ & AR & - & 32 & - & - & 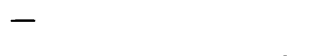 \\
\hline 23 & $\begin{array}{l}\text { Repair of } 1^{\circ} \text { ASD + repair of } \\
\text { cleft mitral and tricuspid } \\
\text { valves; AVR-C/E xenograft } \\
\text { for AS+repair VSD; repair } \\
\text { of periprosthetic leak+ } \\
\text { closure VSD }\end{array}$ & $\begin{array}{r}2 \\
13\end{array}$ & SubA\$/AR & - & 14 & - & - & $\begin{array}{l}\text { Closure of VSD+repair of } \\
\text { cleft mitral valve }\end{array}$ \\
\hline 24 & & & AVs & - & 27 & - & - & - \\
\hline 25 & $\begin{array}{l}\text { Aortic valvotomy; } \\
\text { AVR-homograft for } \\
\text { AS+AR }\end{array}$ & 6 & AVS & - & 18 & - & - & - \\
\hline 26 & $\begin{array}{l}\text { AS+AR } \\
\text { Relief of supraAS }\end{array}$ & $\begin{array}{r}14 \\
4\end{array}$ & AR & + & 12 & - & - & CVG to LAD \\
\hline
\end{tabular}

AR, aortic regurgitation; AS, aortic stenosis; AVS, aortic valve stenosis; AVR, aortic valve replacement; C/E, Carpentier Edwards; CHB, complete heart block; Coarct., coarctation of aorta; Congen., congenital; CVG, coronary vein graft; LAD, left anterior descending; LCA, left coronary artery; Obstr., obstruction; PDA, persisten ductus arteriosus; RCA, right coronary artery; SBE, bacterial endocarditis; SubAS, subaortic stenosis; SupraAS, supra-aortic stenosis; V\$D, ventricular septal defect; $1^{\circ}$ ASD, ostium primum atrial septal defect. 
the homograft and this is achieved with a closely placed continuous suture of $6 / 0$ Prolene.

The upper margin of the homograft is then trimmed and sewn to the transected aorta with a continuous 4/0 Prolene suture.

With a temporary clamp on the right coronary ostium of the homograft the aortic clamp is released after exclusion of air and the new aortic root is observed under pressure (Fig. 1c). This enables haemostasis to be checked and, more important, the best point of attachment of the right coronary to be determined. This is a necessary precaution since the position of the right coronary is variable and may not correspond with the corresponding orifice on the homograft. An appropriate site for the right coronary is chosen; the aortic clamp is reapplied and the right coronary is attached in the same way as the left with a running 6/0 Prolene suture. The complete aortic valve and root replacement is shown (Fig. 1d).

\section{Subjects}

Between May 1976 and August 1980, 26 patients aged 7 to 36 years had total aortic valve and root excision and replacement with a "fresh" aortic homograft together with reimplantation of the coronary arteries.

After operation patients were examined at six monthly or annual intervals with repeated electrocardiograms, phonocardiograms, M-mode echocardiograms, and chest radiographs. Since 1978 two dimensional echocardiography has provided accurate additional information on the state of the aortic root, valve, and subvalvar region.

Recatheterisation was performed in 16 patients three weeks to 21 months after operation when agreed to by the patient and referring physician. Two patients (cases 8 and 16) had a second postoperative catheter study. Gradients across the left ventricular outflow tract were measured at rest and after isoprenaline challenge. At the same investigation, routine biplane ascending aortography to identify the reimplanted coronary arteries and to assess aortic regurgitation and cusp movement, and left ventricular angiography were done.

The dominant lesion for which previous surgery and/or aortic root replacement was performed has been summarised (Table 1).

Twelve patients had one previous operation and seven had two or three previous operations. Only seven had the procedure as a primary operation.

\section{Preoperative state of patients}

\section{CLINICAL}

The age distribution of the patients at the time of operation and the number of patients operated upon each year are shown (Fig. $2 \mathrm{a}$ and $2 \mathrm{~b}$ ). The youngest was 7 years and the oldest was 36 years (mean age 17 years 9 months); 16 were in the second decade. There were 15 male and 11 female patients. Eighteen had symptoms and eight were symptom free.

The indications for operation in the eight patients without symptoms were resting left ventricular outflow tract gradients ranging from 50 to $130 \mathrm{mmHg}$ in five cases or severe aortic regurgitation in three; all had ST-T wave changes in left ventricular leads. The patient with a resting gradient of $50 \mathrm{mmHg}$ had had a fixed subaortic stenosis removed seven years earlier and had developed a deteriorating electrocardiogram; isoprenaline produced a gradient of $100 \mathrm{mmHg}$. Left ventricular hypertrophy was present in 25 of the 26 patients and one had had left bundle-branch block
Fig. 2 The age of patients (a) and the number of patients operated on in each calendar year 1976 to $1980(b)$.

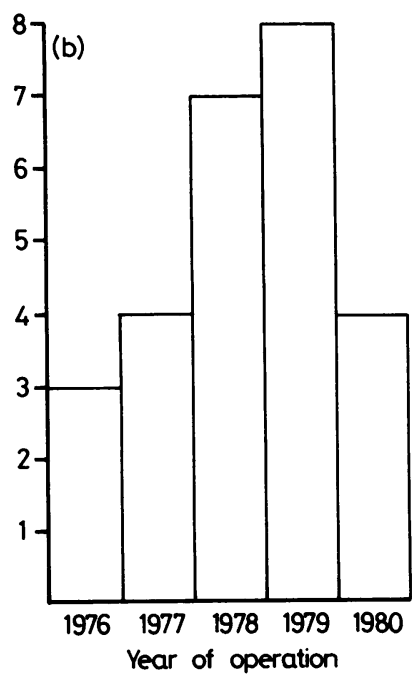

Year of operation

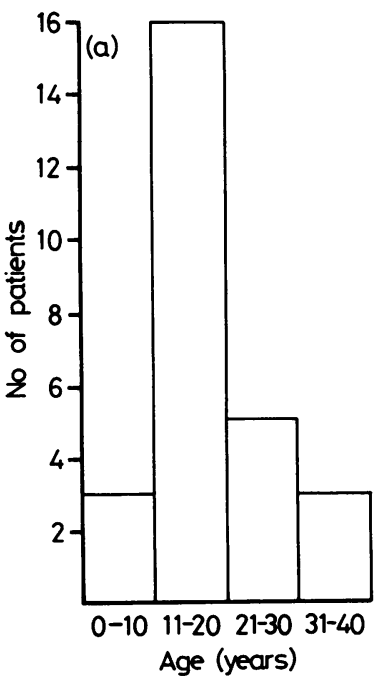


since the previous operation. All were in sinus rhythm.

Other congenital cardiovascular anomalies were present or already treated in $\mathbf{1 0}$ patients. These were; coarctation (two), ventricular septal defect (two), atrial septal defect (one), persistent duct (one), mild pulmonary stenosis (one), left pulmonary artery stenosis (one), double left coronary orifice (one), and mild/moderate mitral regurgitation (five).

In 11 a myotomy was performed, with additional wedge resection of muscle from the massively hypertrophied ventricular septum in nine. One (case 13) had mitral annuloplasty for moderate mitral regurgitation and another (case 23) had repair of a cleft in the mitral valve and closure of a residual ventricular septal defect. One permanent pacemaker was implanted with epicardial leads (case 14) and a large duct was sectioned in case 2 after the aortic root replacement.

\section{Results}

\section{DEATHS}

One patient (case 3), aged 12 years, with tunnel obstruction and anomalous mitral papillary muscle attachment contributing to the obstruction died 48 hours after operation. This papillary muscle could not be excised because chordae were attached along its length, though after a difficult operation (bypass time two hours) the heart came off bypass easily with intermittent atrioventricular block, and there was no residual gradient across the left ventricular outflow tract. He died from left ventricular failure without evidence of valve dysfunction or coronary obstruction.

One late death (case 2) occurred among the 25 survivors at 37 months from the effects of progressive pulmonary hypertension related to the duct closure. This girl's aortic valve function was perfect and at catheterisation one month after operation no resting gradient was present across the competent aortic valve. At the time of operation, after valve replacement, it was noted that the pulmonary artery pressure was $88 / 50 \mathrm{mmHg}$ when the systemic pressure was $120 / 85 \mathrm{mmHg}$ and so the duct was closed. She was an example of the patient with the infantile type of left ventricular outflow obstruction with lumpy aortic valve stenosis and left ventricular disease, who had survived infancy probably because the duct had remained open, allowing shunt reversal and preventing the manifestations and inevitable effects of early left ventricular failure. Clearly the prognosis of the patient would have been better if the duct had been left open.

COMPLICATIONS

One patient (case 8) required five days of balloon counterpulsation after vein grafts to the left anterior descending and marginal branch of the circumflex coronary arteries. She is well, three years later, leading a normal life with a normal electrocardiogram and no residual signs of aortic stenosis. Three patients (cases $4,18,25$ ) required insertion of permanent pacing systems four, 11, and 14 days after operation because of complete heart block. On the second postoperative day one patient (case 7) had a grand mal seizure with episodes of ventricular fibrillation and ventricular tachycardia. Emergency aortic root and valve replacement had been performed because of active bacterial endocarditis; three years later he is free of symptoms with no signs of aortic valve abnormality.

\section{FOLLOW-UP}

The exact status of 22 of the 24 survivors is known to date. Two have not been seen at the National Heart Hospital since discharge after operation; one (case 13) returned to Mauritius and has been seen on television playing football and the other (case 21) refuses to attend as she considers herself normal. She is reported to have no murmurs.

The other 22 patients were free of symptoms and living normal lives one to five years later. None had signs of aortic stenosis. Trivial angiographic aortic regurgitation which was present in four was not audible in any.

New left bundle-branch block appeared in one patient (case 16) immediately after operation and was already present in another. The electrocardiogram showed a reduction in left ventricular hypertrophy in 13 patients, and in five patients the grade of left ventricular hypertrophy remained unchanged. The four patients with permanent pacemakers were pacing satisfactorily and leading normal lives.

Calcification in the homograft aortic walls developed in three aged 7 to 11 years (Fig. 3). The aortic valve cusps were not calcified and continued to show clear opening and closing sounds (see phonocardiogram beneath Fig. 7).

Long-term anticoagulants were not used. Routine prophylaxis for all dental manipulations was advised.

\section{POSTOPERATIVE INVESTIGATION}

Cardiac catheterisation was performed in 16 patients, three weeks to 21 months after operation. Two patients had two studies, one three weeks and 14 months and the other five weeks and eight months after operation. The resting gradients across the left ventricular outflow tract were 0 to $33 \mathrm{mmHg}$ in the 16; all were subvalvar and there were no gradients across the valve (Fig. 4). Nine patients with resting gradients of 0 to $33 \mathrm{mmHg}$ were given isoprenaline which increased the gradients to 33 to $105 \mathrm{mmHg}$ in 


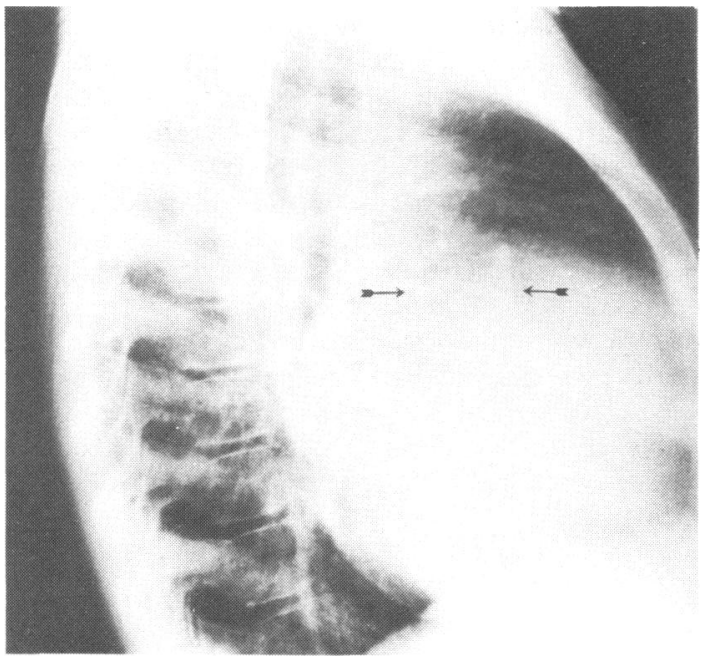

Fig. 3 Lateral chest radiograph from case 2 two years after aortic homograft root and valve replacement showing calcification of aortic wall of the graft root (arrows) which did not involve the aortic cusps.

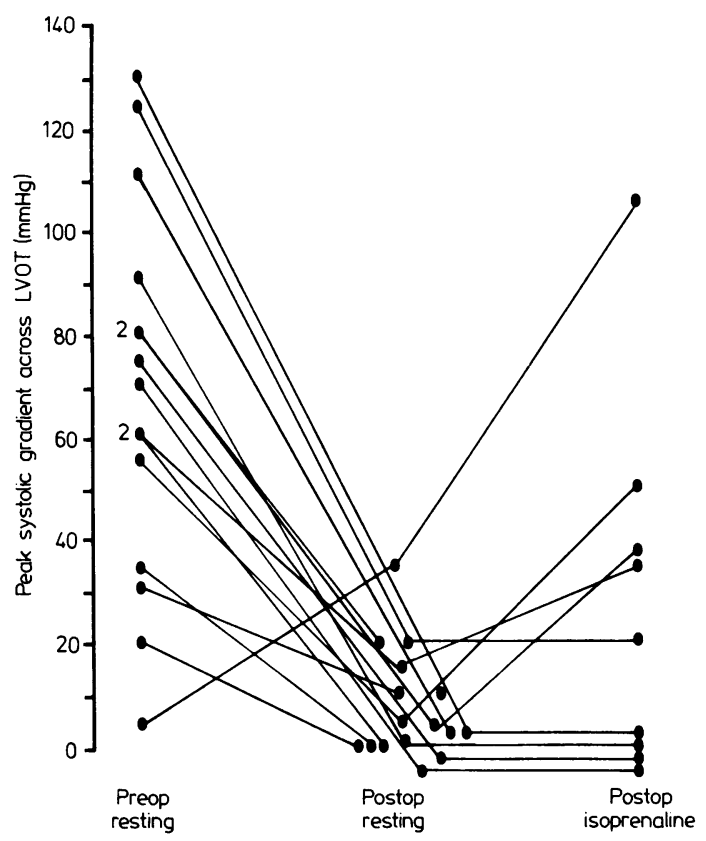

Fig. 4 Peak systolic gradients across the left ventricular outflow tract in 15 patients before operation at rest (one dot represents two patients marked by a 2), at the first postoperative investigation at rest (16 patients, one of whom had no preoperative investigation), and after isoprenaline (nine patients). Seven patients were not given isoprenaline. four but did not change them in five. The boy (case 26) with a stimulated gradient of $105 \mathrm{mmHg}$ had very severe septal bulging and irregular hypertrophy of left ventricular muscle; his first operation was for supraaortic stenosis and he had no gradient before the second operation for aortic regurgitation precipitated by sudden cusp avulsion. The restoration of a competent aortic valve in the presence of severe septal hypertrophy may allow stimulated gradients to occur but it is to be hoped these will disappear as the hypertrophy regresses.

Aortography showed normal looking roots with coronary orifices and arteries well filled in 15 of the 16 patients (Fig. 5a and b). In case 2 the left coronary artery had been repaired at operation and was not seen. The left ventricular outflow seemed to have increased in size and appeared anatomically more normal than before operation (Fig. 6a and b).

The clinical state of the nine patients who have not had postoperative invasive investigation and the reasons they have not been restudied are summarised (Table 2). Two dimensional echocardiography in seven of the nine not invasively investigated and 11 of the 16 restudied patients showed no outflow obstruction, a normally opening aortic valve, and no fluttering of either the aortic or mitral valves. The aortic root appeared slightly thickened in some and normal in others. M-mode echocardiogram showed normal left ventricular cavities and function with a central normal closure line of the homograft aortic valve (Fig. 7a and b). No patient has had endocarditis since operation.

\section{Discussion}

Tunnel left ventricular outflow obstruction may be present when the patient first presents or it may develop with supra-aortic, fixed subaortic, or valvar obstruction, particularly when incomplete relief of the obstruction has been achieved earlier in childhood. Some centres regard tunnel obstruction as being a long subvalvar obstruction, but we consider that it may be part of much more diffuse pathology involving the ascending aorta, often pathologically abnormal, and the annulus. In our experience this problem does not appear when significant aortic regurgitation is produced at the first operation. Though aortic regurgitation may precipitate the need for earlier reoperation it may be better than persistent obstruction since the difficulties posed by a tunnel narrowing are not present. If sudden late aortic regurgitation occurs, as in case 26 who developed cusp avulsion, the tunnel obstruction will remain and produce severe left ventricular failure. Whatever the initial cause of their left ventricular obstruction, patients who acquire tunnel obstruction have diffuse congenital cardiovascular 

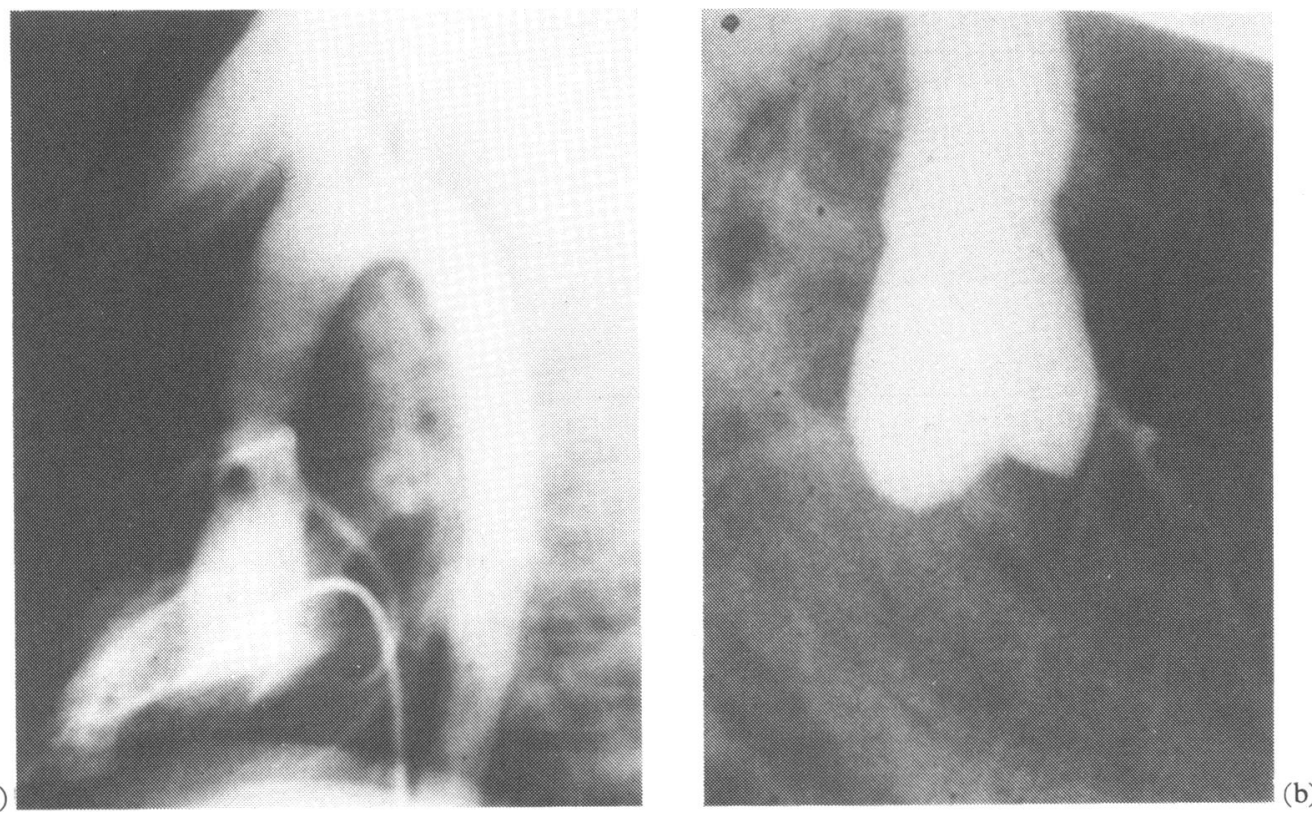

Fig. 5 Angiograms from case 1, an 11-year-old child with lumpy aortic valve stenosis and diffuse tunnel obstruction found at operation but not easily seen in this angiographic view. (a) Left ventricular angiogram-lateral view before operation. (b) Aortogram six months after aortic root and valve replacement by aortic homograft. The aortic valve was competent and looked normal. Both coronary arteries filled normally.
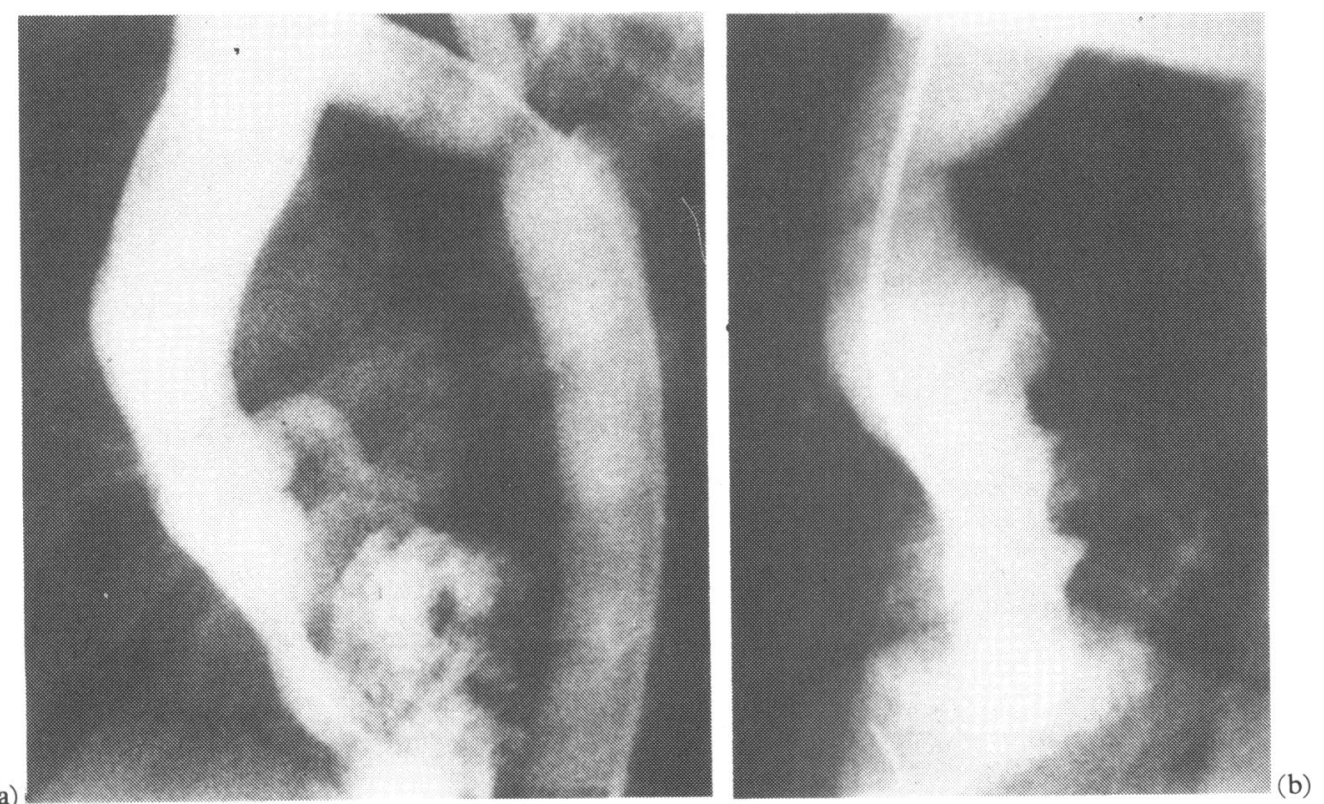

Fig. 6 Left ventricular angiograms from case 18 who had resection of coarctation aged 1 month, open aortic valvotomy aged 5 years, and presented at the age of 8 years with severe aortic valve stenosis and tunnel obstruction. (a) Before aortic root and valve replacement showing small aortic root and ascending aorta, and diffuse narrowing of subvalvar region. (b) Seven months after operation. Aortic root and valve now look normal. The tunnel narrowing is no longer visible though septal bulging remains. The distal suture line of the aortic graft appears slightly thickened. There was no gradient between the left ventricular body and ascending aorta at rest or with isoprenaline stimulation. 
Table 2 Summary of nine patients who have not had postoperative investigation

\begin{tabular}{|c|c|c|c|c|c|c|c|}
\hline $\begin{array}{l}\text { Case } \\
\text { No. }\end{array}$ & Symptoms & Electrocardiogram & Problems & $A R$ & $\begin{array}{l}\text { Reason for } \\
\text { refusal }\end{array}$ & $\begin{array}{l}\text { Follow-up } \\
\text { time }(y)\end{array}$ & State \\
\hline $\begin{array}{r}4 \\
7 \\
10 \\
13\end{array}$ & $\begin{array}{l}- \\
-\end{array}$ & $\begin{array}{l}\text { CHB } \\
\text { ISQ } \\
\text { Improved } \\
?\end{array}$ & $\begin{array}{l}\text { Pacemaker } \\
= \\
-\end{array}$ & $\frac{-}{?}$ & $\begin{array}{l}\text { Patient } \\
\text { Patient } \\
\text { Physician } \\
\text { Patient in } \\
\text { Mauritius }\end{array}$ & $\begin{array}{l}4 \\
4 \\
3\end{array}$ & $\begin{array}{l}\mathbf{N} \\
\mathbf{N} \\
\mathbf{N}\end{array}$ \\
\hline $\begin{array}{l}17 \\
21 \\
22 \\
23 \\
25\end{array}$ & $\begin{array}{l}z \\
z \\
z\end{array}$ & $\begin{array}{l}\text { Improved } \\
\text { ? } \\
\text { LBBB } \\
\text { ISQ } \\
\text { CHB }\end{array}$ & $\begin{array}{l}\bar{z} \\
\bar{z} \\
\text { Pacemaker }\end{array}$ & $\begin{array}{l}z \\
\overline{-}\end{array}$ & $\begin{array}{l}\text { Patient } \\
\text { Patient } \\
\text { Physician } \\
\text { Inadvisable } \\
\text { Physician }\end{array}$ & $\begin{array}{l}2 \\
2 \\
1 \\
1 \\
1\end{array}$ & $\begin{array}{l}\mathbf{N} \\
\mathbf{N} \\
\mathbf{N} \\
\mathrm{N}\end{array}$ \\
\hline
\end{tabular}

AR, aortic regurgitation; CHB, complete heart block; LBBB, left bundle-branch block; ISQ, unchanged; N, normal; Patient, patient refuses; Physician, referring cardiologist refuses.

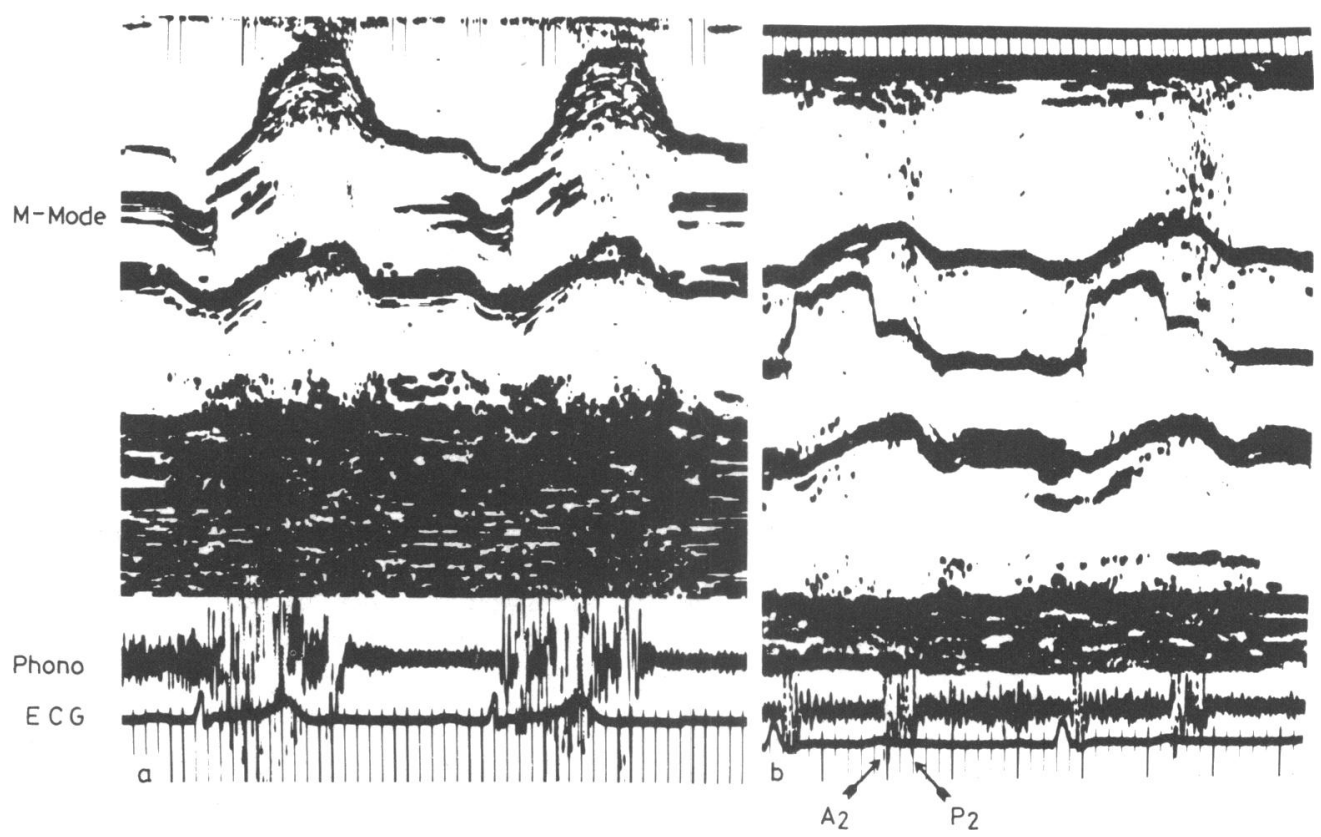

Fig. 7 M-mode echocardiogram and phonocardiogram from case 11 with aortic valve stenosis. (a) Before operation. This shows thickened aortic valve with central abnormal opening and closure. (b) After homograft aortic root and valve replacement with normal opening of pliable normal aortic valve cusps. The intense systolic murmur has disappeared and aortic valve closure (A2) is clear and normal.

abnormality ${ }^{6}$ and can be recognised before the first operation.

Tunnel obstruction is difficult to relieve by the conventional replacement or repair operations for congenital aortic stenosis. Various techniques have been tried such as leaving the lesion in situ and adding a further anomaly in the form of an apico-aortic conduit ("Texas tube") 7 or transecting the ventricular septum (Konno) and inserting a prosthetic valve replacement. ${ }^{89}$ Both provide relief of the obstruction but long term follow-up is unknown and additional anomalies added to the heart are the price of relieving the haemodynamic problem. The speed of degeneration in the valves or conduits used will greatly influence the late results. Glowing reports of a low mortality may make these other procedures sound attractive but the results should be correctly judged by the long term follow-up and complications in such a young group of patients.

Fresh aortic homografts have proved to be a good substitute for the diseased aortic valve and do not require anticoagulant therapy. ${ }^{10-12}$ These are ideal $\sigma^{\circ}$ 
for young patients and particularly women of child bearing age. Valve replacement alone, however, is often inadequate to relieve the outflow obstruction in these tunnel obstructions and is difficult to site in the small root. Once the root is excised the picture changes because the whole area opens widely enough to accept an adult sized graft in patients over 5 years of age.

Though this is a more complex procedure than a valve replacement it provides complete relief of the dynamic problems. We feel it is justified as the main aim of surgical treatment in congenital aortic stenosis is to produce or preserve normal left ventricular function. Inevitably, problems are likely to arise during the learning phase of any new surgical venture. Their recognition and solution is preferable to a denial of the value of a procedure because of early morbidity and mortality. Operative morbidity has been related to two problems: the siting of the coronary vessels and trauma to the conducting tissue.

Early in the series it was recognised that a patient would come off bypass easily but would develop deteriorating left ventricular function as the systemic pressure rose. It was clear that the left coronary artery flow was compromised but careful examination on bypass at first failed to demonstrate a cause. It became apparent that the difficulty was the result of tension on the left coronary artery which was stretched by the distended adult sized aortic sinus to meet the orifice of a much bigger adult aortic root homograft. Coronary grafts were necessary to salvage this situation. In all subsequent cases, free mobilisation of the left coronary artery has prevented this complication. Case 26 had a coronary graft as a prophylactic measure, as initially left ventricular function appeared compromised. Subsequent angiography confirmed coronary artery patency with normal flow.

Another important technical development has been to attach only the left coronary artery and then complete the upper homograft anastomosis. As the aorta becomes distended it becomes clear where the most appropriate site for anastomosis of the right coronary lies. This site may not coincide with the position of the right coronary orifice on the homograft. The left coronary orifice position, on the other hand, is usually constant at the mid-point of the left coronary sinus. The position of the right coronary artery is notoriously inconstant and this technique prevents malpositioning of the right coronary anastomosis.

Heart block was distressingly common at first but has only occurred once in the last eight patiens-a girl having her third operation. The cause was too low an excision of the root in the region of the membranous septum between the right and non-coronary cusps or the subsequent placing of attaching sutures. This complication can be avoided by attention to the vul- nerable segment of ventricular septum.

As yet, in the short period of follow-up of one to five years, there have been no other complications and no evidence of progressive damage to the conducting tissue or the coronary arteries. The valves presumably, like other homografts and autografts, must be liable to infective endocarditis and thus the patients should receive careful advice about prophylaxis, though this complication had not in fact occurred. Another hazard of a tissue valve is that it may be infected at the time of insertion when sterilised in antibiotic solutions, but this is now extremely rare in our laboratory. A greater problem is the availability of material which may prevent many centres using this technique.

Calcification occurs sooner or later in all biological graft material whether homograft, xenograft, dura mater, pericardium, or fascia lata. Experience of aortic valves on the right and left side of the heart shows that it occurs early in the graft aortic wall but only exceptionally affects the cusps during the first decade of follow-up. In patients under 10 years it was radiologically apparent by the end of the second year but the cusps remained pliable, opening and closing normally without regurgitation, and the coronary orifices are widely patent. The long-term record of homografts, however imperfect, is far superior to that of xenografts, pericardial valves, and dura mater in younger patients.

It is accepted that a further operation will be needed eventually as with any valve replacement. If the homograft valve and root behaves as it does after right ventricular outflow tract reconstruction in patients from the same age group then it should not be required until the second decade of follow-up. The technical problems this will involve have yet to be discovered. Since a disc of native aorta has been left around the coronary orifices, they should not become obstructed.

Clearly this operation provides excellent relief of fixed and dynamic obstruction. Its use has been extended to other forms of aortic valve and root disease such as severe aortic regurgitation and ring destruction by infection where it is difficult to site a conventional homograft or autograft.

In view of these results it is now our policy to use this technique for all tunnel obstructions with small or diseased aortic roots. It is also indicated in those young patients with aortic regurgitation and important ring dilatation and in selected patients with active aortic valve endocarditis.

We are indebted to Susan Stone, research secretary, supported by an anonymous donor, who collected and collated the information. We thank Dr A Rickards for allowing us access to the haemodynamic data from 
postoperative investigations, Dr Simon Rees for help in interpreting the angiograms, and Barbara Hyams for the surgical drawings.

\section{References}

1 Spencer FC, Neill CA, Sank L, Bahnson HT. Anatomical variations in 46 patients with congenital aortic stenosis. Am Surg 1960; 26: 204-16.

2 Maron BJ, Redwood DR, Roberts WC, Henry WL, Morrow AG, Epstein SE. Tunnel subaortic stenosis. Left ventricular outflow tract obstruction produced by fibromuscular tubular narrowing. Circulation 1976; 54: 404-16.

3 Presbitero P, Somerville J, Revel-Chion R, Ross D. Open aortic valvotomy for congenital aortic stenosis: late results. Br Heart f 1982; 47: 26-34.

4 Somerville J, Stone S, Ross D. Fate of patients with fixed subaortic stenosis after surgical removal. Br Heart $\mathrm{f}$ 1980; 43: 629-47.

5 Somerville J, Ross DN. Atypical aortic valve stenosis-a diffuse congenital cardiovascular disease-recognition and surgical management (abstract). Br Heart f 1977; 39: 930.

6 Somerville J. Congenital cardiovascular disease or congenital heart disease-A time for change in concepts? In: Becker AE, Losekoot G, Marcelletti C, eds. Paediatric cardiology. vol 3. Edinburgh: Churchill Livingstone, 1981: 324-45.

7 Cooley DA, Norman JC, Mullins CE, Grace RR. Left ventricle to abdominal aorta conduit for relief of aortic stenosis. Cardiovascular Diseases, Bulletin of the Texas Heart Institute 1975; 2, no. 3: 376-83.

8 Konno S, Imai Y, Iida Y, Nakajima M, Tatsuno K. A new method for prosthetic valve replacement in congenital aortic stenosis associated with hypoplasia of the aortic valve ring. $\mathcal{F}$ Thorac Cardiovasc Surg 1975; 70: 909-17.

9 Björnstad PG, Rastan H, Keutel J, Beuren AJ, Koncz J. Aortoventriculoplasty for tunnel subaortic stenosis and other obstructions of the left ventricular outflow tract. Clinical and haemodynamic results. Circulation 1979; 60: 59-69.

10 Ross DN. Homograft replacement of the aortic valve (letter). Lancet 1962; ii: 487.

11 Barratt-Boyes BG. Long-term follow-up of aortic valvar grafts. Br Heart $\mathcal{F}$ 1971; 33, suppl: 60-5.

12 Bodnar E, Wain WH, Martelli V, Ross DN. Long-term performance of $\mathbf{5 8 0}$ homograft and autograft valves used for aortic valve replacement. Thorac Cardiovasc Surg 1979; 27: 31-8.

Requests for reprints to $\mathrm{Dr}$ Jane Somerville, Paediatric and Adolescent Unit, National Heart Hospital, Westmoreland Street, London W1M 8BA. 